\title{
A new species of Ivdelinia Andronov, 1961 from the Moroccan Givetian and its palaeoecological and palaeobiogeographical implications
}

\author{
FULVIO FRANCHI, MENA SCHEMM-GREGORY \& CHRISTIAN KLUG
}

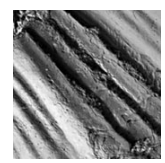

\begin{abstract}
The collection and study of benthic fauna from Middle Devonian carbonate buildups of the Maïder Basin in the eastern Anti-Atlas of Morocco permitted the taxonomic revision of previously described brachiopods from this area. Rhynchonellids dominate the brachiopod fauna. In this work, however, the focus is put on the description of a new gypidulid species, Ivdelinia pulchra, which belongs to the family Gypidulidae (subfamily Ivdelininae), found among the brachiopods from the Aferdou el Mrakib reef mound. It represents the youngest Ivdelinia species so far described and is compared with other ivdelinids. Ivdelinia pulchra occurs as densely packed communities which lived in a carbonate predominant environment during the earlier stage of reef mound growth, suggesting a more or less allochthonous state of these communities. However, this taxon does not properly belong to the reef guild. In addition we discuss the palaeoecology of the new species. $\bullet$ Key words: Ivdelinia, Pentamerida, palaeoecology, palaeobiogeography, Maïder, Morocco, Givetian.
\end{abstract}

\begin{abstract}
FRANCHI, F., SCHEMM-GREGORY, M. \& KLUG, C. 2012. A new species of Ivdelinia Andronov, 1961 from the Moroccan Givetian and its palaeoecological and palaeobiogeographical implications. Bulletin of Geosciences 87(1), 1-11 (4 figures). Czech Geological Survey, Prague. ISSN 1214-1119. Manuscript received June 30, 2011; accepted in revised form December 19, 2011; published online February 2, 2012; issued February 29, 2012.

Fulvio Franchi (corresponding author), Dipartimento di Scienze della Terra e Geologico Ambientali, Università di Bologna, via Zamboni, 6740126 Bologna, Italy; fulvio.franchi2@unibo.it • Mena Schemm-Gregory Centro de Geociências da Universidade de Coimbra, Largo Marquês de Pombal, P-3000-272 Coimbra, Portugal; Mena.Schemm-Gregory@dct.uc.pt • Christian Klug, Paläontologisches Institut und Museum, Universität Zürich, Karl Schmid-Strasse 4, CH-8006 Zürich, Switzerland; chklug@ pim.uzh.ch
\end{abstract}

The occurrence of many Devonian mounds in the Tindouf Basin (Dumestre \& Illing 1967), in the Sebkha Azzel Matti (Wendt et al. 1997), and in the Moroccan eastern Anti-Atlas is well documented in literature, particularly the Anti-Atlas Tafilalt (Choubert et al. 1952; Le Maître 1952; Hollard 1963, 1967, 1974, 1981a, 1981b; Massa et al. 1965; Michard 1976; Brachert et al. 1992; Aitken et al. 2002; Klug et al. 2009), and Maïder Basin (Wendt 1993; Kaufmann 1995, 1996, 1997, 1998a, b).

The Maïder Basin (Fig. 1) offers one of the most impressive outcrops of Devonian mounds. Hollard (1974) was the first who mentioned the 4 mud mounds at Jebel el Oftal, the solitary mud mound at Guelb el Maharch, and the reef mound named Aferdou el Mrakib in the Maïder Basin (Fig. 2). Because of their shape and lithology, these mounds are very similar to the Kess Kess mounds of Hamar Laghdad (Tafilalt) which are well studied by Brachert et al. (1992), Belka (1998), and Aitken et al. (2002). Even though they have been studied for decades, the origin of the carbonate buildups of the Maïder Basin is still under debate and detailed descriptions of strategic taxa, e.g. brachiopods, could provide new palaeoecological data useful for inferring their genesis.

The aim of this paper is to provide a detailed description of the taxon Ivdelinia pulchra sp. nov., which is part of the Aferdou el Mrakib reef guild. The other specimens collected during the field survey in February 2011 belong to the orders Spiriferida, Orthida, and Athyridida. Only a few strophomenids were found in another mound locality. Ivdelinia pulchra sp. nov. occurs in various situations: it can be found in monospecific shell beds (see Klug et al. 2009), sometimes, associated with abundant specimens of the gypidulid Devonogypa (which reaches almost $80 \mathrm{~mm}$ shell length) in low diversity associations together with some other brachiopods, and sometimes, it can be found in free association with the variable fauna of the Aferdou el Mrakib reef mound. Andronov (1961) established the genus Ivdelinia with the type species I. ivdelensis (Khodalevich, 1951) from the Ural Mountains and included 4 European and 32 Russian species, most of which he 


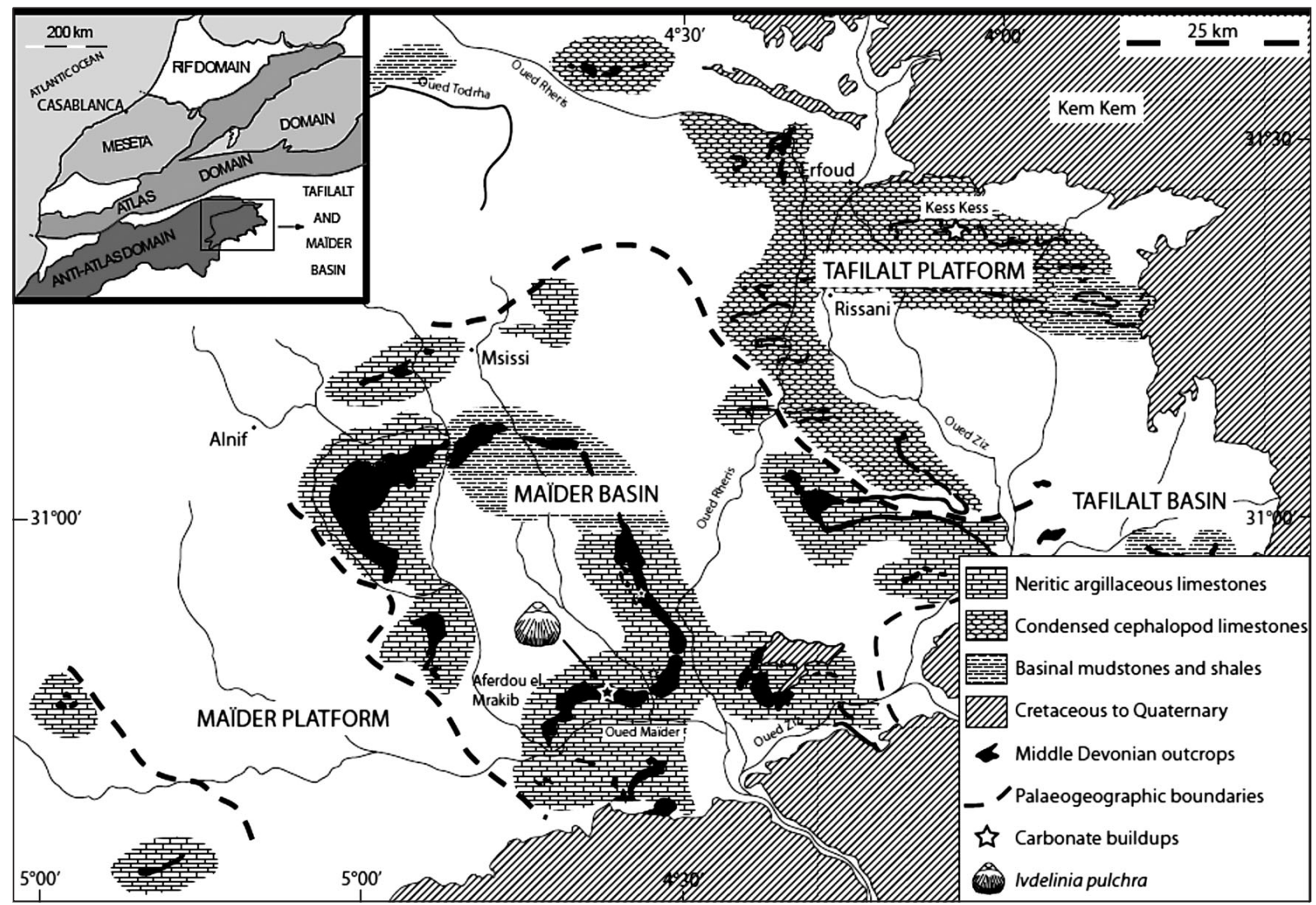

Figure 1. Geological schematic map of the eastern Anti-Atlas (modified after Kaufmann 1996). In the box, the tectonic domain is indicated (modified from Michard 1976). The three stars indicate the carbonate buildup localities. Collecting localities of Ivdelinia pulchra sp. nov. are indicated by the brachiopod symbol.

established in this monograph. Biernat (1966), however, considered Ivdelinia only as a subgenus of Gypidula Hall, 1867 and argued that splitting of ribs is not a generic-level character because it is only recognizable in adult specimens. Jux (1969) followed Biernat (1966) in his study of the German Devonian gypidulids and Godefroid (1972) regarded Ivdelinia as a genus, redescribed the type species, and figured detailed serial sections. Malygina \& Sapelnikov (1973) and Sapelnikov (1985) described further taxa from Lower Devonian and Eifelian strata of the Ural Mountains and Central Asia. Brice (1982) subdivided the genus into two subgenera with material from Arctic Canada based on the presence and absence of a ventral median septum. Blodgett \& Boucot (1999) reported the first species from Alaska and proposed its relationship to Ivdelinia species from the Urals. Even though a lot of taxonomic work has been done so far on this genus, the systematic description of North African material, which first was mentioned in literature almost two decades ago is still lacking until now.

Institutional abbreviations. - MGGC - Museo Geologico Giovanni Capellini, Bologna, Italy.

\section{Geological setting}

The Anti-Atlas is one of the external parts of the VariscanAppalachian-Ouachita-Mauritanides orogen (Burkhard et al. 2006). Palaeozoic deposits in the eastern Anti-Atlas of Morocco are included in a continental shelf sequence developed on the northwestern margin of Gondwana during Late Precambrian to Early Carboniferous time. The closure of the western Paleo-Tethys and consequent clockwise Gondwana rotation during the Devonian resulted in a gradual formation of two main intracratonic non-folded sedimentary basins, the Maïder and Tafilalt basins, which correspond to the Maïder and Tafilalt platforms (Wendt 1985). The Devonian sediments were deposited in these platform-basin systems in a wide epicontinental sea at a paleolatitude of approx. $60^{\circ}$ south of the palaeo-equator (Stampfli \& Borel 2002). This platform basin system was in place from the early Variscan tensional stress on the passive continental margin of northwest Gondwana (Wendt 1985, 1988). Variscan compression exposed the Palaeozoic rocks in WE and NW-SE trending synclines.

The Maïder region is situated south of Msissi (Fig. 1), where the Devonian strata crop out in a $50 \mathrm{~km}$ 

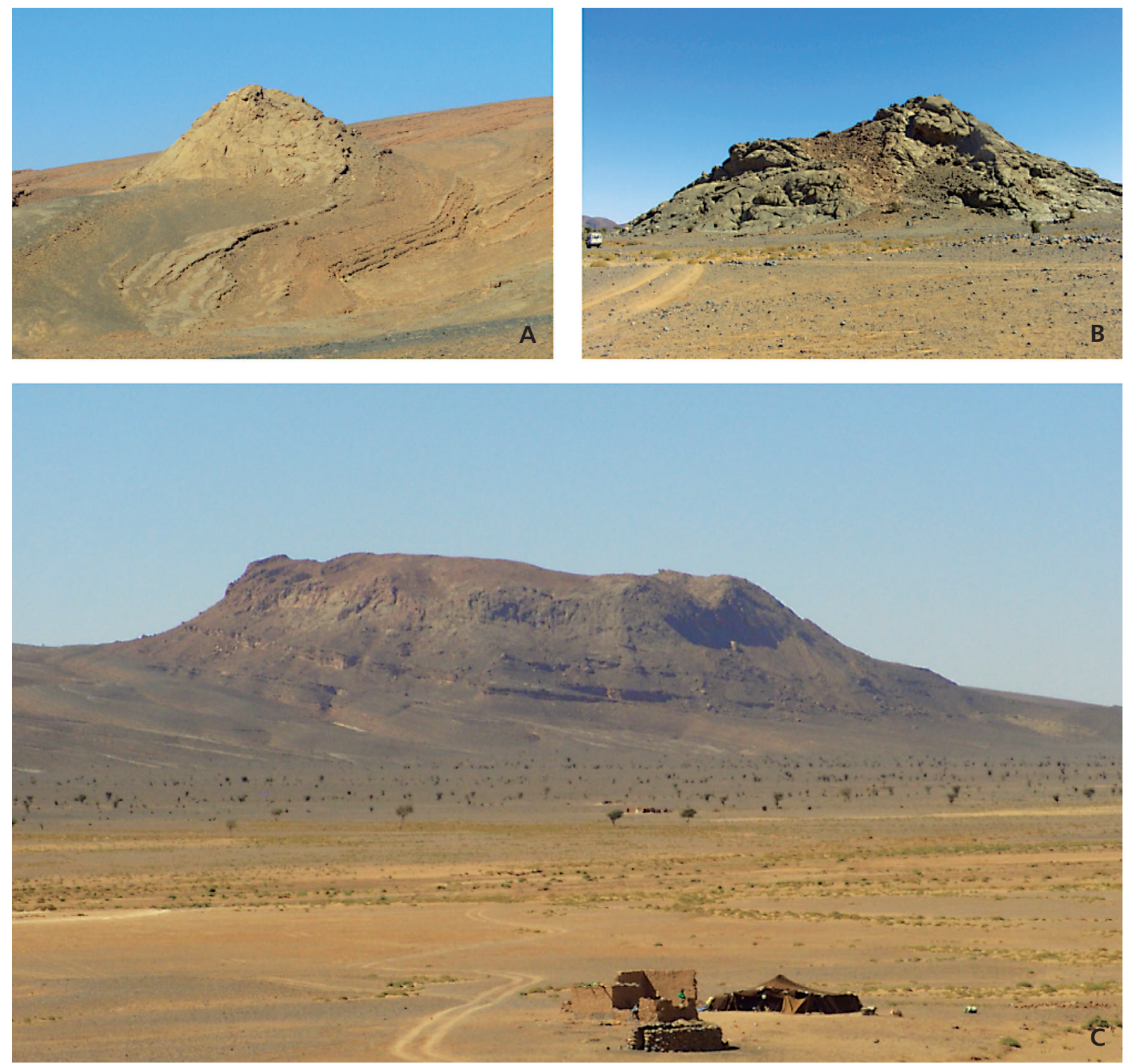

Figure 2. The carbonate buildups. $\bullet$ A - mound number 2 at the Jebel el Oftal, the largest in this locality, ca 40 meters high. $\bullet$ B - Guelb el Maharch solitary mound seen from W, ca 40 meters high. C - Aferdou el Mrakib reef mound seen from NE, 100-130 meters high.

wide amphitheater-like structure. The carbonate buildups lie on top of a 200-300 m thick Middle Devonian succession of argillaceous, fossiliferous limestones (Hollard 1974, Wendt 1993). During the Late Devonian, the Maïder Basin was filled by a succession of approx. $800 \mathrm{~m}$ of shales and sandstones, which correspond to just some tens of meters of cephalopod limestone in the Maïder Platform (Wendt 1991). Afterwards, Upper Devonian/ Lower Carboniferous marine siliciclastic deposits leveled both the platform and the basin.

\section{Carbonate buildups}

The long lasting debate on the origin of the carbonate buildups of the Maïder Basin roots in two main problems: their genesis and the control of their stratigraphic position. Kaufmann (1998a) suggested a microbial origin for the carbonates of the Maïder Basin mud mounds, in spite of the microbial structures only being preserved in stromatactis fabrics, and concluded that changes of the physico-chemical parameters of the water would have allowed the microbial communities to fix the $\mathrm{CaCO}_{3}$ in their biofilms (Chafetz \& Bucrynski 1992, Monty 1995) consolidating the steep flanks of the carbonates buildups. This hypothesis is also supported by high accumulation rates of the mound facies, greater than in the off-mound facies, purity of mound carbonates (95\% $\mathrm{CaCO}_{3}$ ), and homogeneous calcite mineralogy (Kaufmann 1996), which suggests an authigenic origin.

The scattered occurrence of the carbonate buildups can hardly be explained by the presence of cold seeps and/or 
hot vents on the sea floor (e.g., Belka 1998). Geochemical data do not support this suggestion unequivocally. Methane seepages are not supported by the ${ }^{13} \mathrm{C}$-values of the mound carbonates which suggest normal marine conditions, and the ${ }^{18} \mathrm{O}$-values do not indicate a sufficiently elevated temperature to suggest any hydrothermal activity (Kaufmann 1997). Nevertheless, Aferdou el Mrakib and Guelb el Maharch carbonate buildups appear to be aligned with a Precambrian E-W trending strike-slip fault system (Kaufmann 1998a) that could be a preferential way for deep fluids. It cannot be excluded, therefore, that the development of the carbonate buildups was initiated with a low temperature hydrothermal water seepage and subsequent benthic fauna colonization. Mixing with the normal sea-water might also explain the near-normal isotopic values. In the case of the Algerian mud-mounds, the fault alignment is evident (Wendt et al. 1993).

\section{Aferdou el Mrakib}

Kaufmann $(1996,1997)$ established the age of the Maïder carbonate buildups by the study of conodont faunal associations formerly described by Belka et al. (1997). The stratigraphical position of the Aferdou el Mrakib mound spans the hemiansatus to the early varcus conodont zones (Givetian). The Aferdou el Mrakib reef mound with its approx. $900 \mathrm{~m}$ diameter and $100-120 \mathrm{~m}$ altitude is the largest reef mound of the Anti-Atlas (Fig. 2c). The Aferdou el Mrakib fauna is enriched in macroscopic organismal remains compared to the other Maïder Basin carbonate buildups, Kaufmann (1998b) provided a broad description of the faunal assemblage from this carbonate buildup. The reef rocks are dominated by in situ and detrital crinoids, tentaculitids (tentaculites, styliolinids and rare nowakiids), tabulate corals such as auloporids (Bainbridgia, Cladochonus, Remesia, Aulocystis), striatoporoids (Pachystriatopora), thamnoporids (Thamnopora), favositids (Platyaxum), heliolitids (Heliolites, large mamelons up to almost one meter), rugose corals, both solitary (Heliophyllum, Cystiphylloides, Acanthophyllum, Macgeea) and colonial (Hexagonaria, Phillipsastrea). The Aferdou el Mrakib mound also yields one of the most abundant brachiopod guilds of the Maïder Basin which consists of pentamerids (Ivdelinia, Devonogypa), spiriferids (Atrypa, Desquamatia, Planatrypa, Carinatina), orthids (Schizophoria), athyrids, and leptaenid strophomenids.

Despite of the abundance of in situ frame builders (stromatoporoids, tabulate and rugose corals), framestones and boundstones (as described by Wright 1992) are lacking in this buildup. Several stromatoporoids (Actinostroma) only appear to locally bound other bioclasts. According to Fagerstrom's (1991) theory of reef guilds, the Aferdou el Mrakib fauna is compatible with a constructor guild and a baffler guild. The predominance of stromatoporoids and rugose corals as well as the absence of calcareous green algae suggests a moderately shallow environment below the euphotic zone (Kaufmann 1995, 1996).

The entire buildup is made up of stromatactis-bearing wackestones, floatstones, and rudstones. Bioclasts are mainly crinoids, corals and subordinate brachiopods. The concordance between the bottom of the stromatactis structures and the strata dip seem to suggest a synsedimentary origin for these cavities. Neptunian dikes filled by dark to violet micrite and a variety of cements cut across the Aferdou el Mrakib buildup. The topmost southeastern part of the buildup is pervasively dolomitized and fossils and structures, therefore, have been obliterated or at least were overprinted by dolomitization. Whereas at the Aferdou el Mrakib mound the fossil remains are more than in other buildups of the Maïder Basin, the taxonomic composition seems to be the same in all the studied places.

\section{Materials and methods}

All studied brachiopods were collected by FF and CK in February and March 2011 from the Aferdou el Mrakib reef mound along the Maïder Basin (Fig. 1). Further information on the localities are provided by Wendt (1993) and Kaufmann (1995, 1996, 1997, 1998a, b).

The specimens described here are deposited at the Museo Geologico Giovanni Capellini of the University of Bologna (Bologna, Italy) with the serial numbers MGGC 21835-21844.

Petrographic and palaeontological investigations of the samples collected during the field survey are currently under investigation by FF. Specimens are preserved as shell material and coated with magnesium oxide prior to photographing. In the present paper the brachiopod taxonomy systematics follows the revised Treatise on Invertebrate Paleontology (Blodgett et al. 2002).

\section{Systematic palaeontology}

Order Pentamerida Schuchert \& Cooper, 1931

Suborder Pentameridina Schuchert \& Cooper, 1931

Superfamily Gypiduloidea Schuchert \& LeVene, 1929

Family Gypidulidae Schuchert \& LeVene, 1929

Subfamily Ivdeliniinae Sapelnikov, 1985

Genus Ivdelinia Andronov, 1961 Subgenus Ivdelinia (Ivdelinia) Andronov, 1961

Type species. - Gypidula ivdelensis Khodalevich, 1951, p. 22. 
Diagnosis. - Ivdelinia with strongly raised costae or plicae and with median septum. [After Blodgett et al. (2002), p. 1014.]

Stratigraphic and geographic occurrence. - Lochkovian to Givetian (lower Lower to upper Middle Devonian); Ural Mountains, Central Asia, Siberia, Uzbekistan, Alaska (USA), Arctic Canada, Europe (Germany, Belgium, Czech Republic), North Africa.

\section{Ivdelinia pulchra sp. nov.}

Figure 3

1998b Ivdelinia sp. Kaufmann, pl. 13, fig. 11.

Derivation of name. - From the Latin word pulcher, pulchra, pulchrum = beautiful.

Holotype. - Articulated, but broken, specimen showing the spondylium stored in the Museo Geologico Giovanni Capellini, Bologna, Italy, under the inventory number MGGC 21842a.

Type horizon and locality. - Lens of gray to dark gray crinoidal wackestone to floatstone with abundant organic matter. Lower Givetian, northeastern flank of Aferdou el Mrakib reef mound, Maïder Basin, Anti-Atlas, Morocco.

Material. - 2 articulated specimens, 8 external ventral valves, 1 fragment of internal ventral valve (MGGC 21835-21844).

Stratigraphic and geographic distribution. - Lower Givetian (probably hemiansatus conodont zone); Maïder Basin, Morocco.

Diagnosis. - Large Ivdelinia with 3 to 5 plications on fold which show furrows in the anterior third of valve. Fold bordering plications almost parallel and higher than fold. Sulcus tongue clearly developed with straight anterior margin.

Description. - Shells medium to large-size, strongly ventribiconvex to planoventriconvex. Hinge line strophic. Almost entire shell covered by plications which are diminishing on flanks toward the lateral ends. Plications split by furrows in the anterior third of valve. Sulcus moderately broad, sulcus bordering plications coarser than plications of fold and sulcus and usually higher elevated than fold. Fold flat to U-shaped in cross-section. Sulcus tongue clearly developed, box-like in anterior view, and with straight anterior margin. Dorsal valve always wider than long. Ventral median septum clearly developed, high, and long, reaching to at least half of shell length. Spondylium gypiduloid (see Blodgett et al. 2002, fig. 621.12). Microornamentation not preserved.

Discussion. - A vast number of taxa of Ivdelinia are described, especially from the Ural Mountains (Russia), some of which can probably be rejected as already stated by Biernat (1966). It is beyond the scope of this work, to revise all species of Ivdelinia, especially because we could not study the type or topotype material of these taxa. Therefore, we discuss the new species only from literature data and external morphology of illustrated specimens. If no other indication is provided, the compared taxa are from Lower Devonian-Eifelian strata of the Ural Mountains. Ivdelinia pulchra sp. nov. differs from I. ivdelensis (Khodalevich, 1951) in wider forms, and fewer and broader ribs on flanks. Ivdelinia acutolobata (Sandberger \& Sandberger, 1850-1856) including its cf.-forms from the Ural Mountains, the Holy Cross Mountains (Poland), and Germany has smooth flanks or flanks covered with one or two weak plications and only one plication in the sulcus and only 2 plications on the fold, which also represent its bordering plications. Ivdelinia sp. cf. I. multiplicata (Roemer, 1854) figured by Biernat (1966, pl. 2, figs 2-4) has many more and finer plications than I. pulchra, while the specimens of I. multiplicata figured by Andronov (1961, pl. 3, figs 11-17) show a smaller sulcus tongue and only very short furrows in the anterior part of the plications. Ivdelinia pseudoivdelensis (Khodalevich, 1951) is probably a juvenile form of another Ivdelinia species, but the specimen figured in Andronov (1961, pl. 4, figs 24-27) shows very short furrows in the plications and coarser sulcus bordering plications than I. pulchra. Ivdelinia geniculatis Andronov, 1961 is wider, smaller, and has more plications on the fold than our new species. Ivdelinia menneri Andronov, 1961 has many more and finer plications, I. archangalskii Andronov, 1961 also has finer plications and a more transverse outline than I. pulchra. Ivdelinia krestovnikovi Andronov, 1961 has fewer and coarser ribs than I. pulchra and broader fold and sulcus bordering plications. Ivdelinia milradowitchi Andronov, 1961 has a posteriorly smooth shell, its fold is almost inconspicuous, but shows a coarse median furrow, whereas the complete external surface in I. pulchra is covered by plications with furrows of equal size. Ivdelinia uralensis Andronov, 1961 has in general plications of the same size as I. pulchra, however, the median costa of the sulcus is remarkably coarse, but specimens are smaller than in the new species. Flanks in I. egorovi Andronov, 1961 are smooth and its fold is not U-shaped in cross-section. Furthermore, specimens are smaller than in I. pulchra. Ivdelinia savtschencoi Andronov, 1961 differs from the new species in having smaller and more transverse specimens with fewer plications. The representatives of I. petropavlowskiensis Andronov, 1961 show coarser plications on the fold and larger furrows on the plications than in I. pulchra. Ivdelinia 
antiqua Andronov, 1961 has smaller forms with a less distinct sulcus tongue and coarser plications than the new species. Ivdelinia motovilichaensis Andronov, 1961 has a higher elevated fold and higher plications than I. pulchra. Ivdelinia intima Andronov, 1961 and I. pulchra show plications of the same size. Nevertheless, I. intima has a subcircular, rather than transverse outline and larger furrows on its plications than the new species. Ivdelinia planosella Andronov, 1961 is questionably regarded as a species of Ivdelinia because the furrows on the plications are not visible on the figured specimen (Andronov 1961, pl. 7, figs 16-18). This taxon has finer plications than I. pulchra. Ivdelinia apera Andronov, 1961 has coarser plications than the new species and an inconspicuous fold. The dorsal valves of I. planosella and I. aspera are not illustrated. The plications of I. crassicosta Andronov, 1961 are more distinct and coarser than in I. pulchra. Ivdelinia rossica Andronov, 1961 differs from I. pulchra in having finer costae and more transverse and smaller specimens. In contrast to I. pulchra, I. moldawanzewi Andronov, 1961 is smaller with a thinner fold and fewer plications on the flanks. Ivdelinia moldawanzewi form alpha Khodalevich \& Breivel, 1959, differs from the new species also in smaller intercalated plications on the fold and in the sulcus. The plications in I. soswaensis Andronov, 1961 are sharper and specimens of this taxon are smaller and show a broader sulcus than I. pulchra. Representatives of I. trivialis Andronov, 1961, I. pulchellis Andronov, 1961, and I. kelleri Andronov, 1961 are very similar to each other and all are forms smaller than I. pulchra, with fewer plications on the fold and mostly possess a very pronounced median plication in the sulcus. Ivdelinia sarytchevi Andronov, 1961 is smaller and has a broader sulcus and a broader fold than I. pulchra. Ivdelinia ataevi Andronov, 1961 is quite similar to I. pulchra, but differs from the new species in being smaller, having a deeper sulcus, and larger furrows on the plications. Ivdelinia sphaerica Andronov, 1961 is subcircular instead of transverse, smaller, and shows a less elevated fold, and larger furrows on the plications than I. pulchra. Ivdelinia simplex Andronov, 1961, I. maslovi Andronov, 1961, and I. karjavini Andronov, 1961 are all smaller and have coarser plications with no or shorter furrows than I. pulchra. Ivdelinia procerula (Barrande, 1879) from the Barrandian region (Czech Republic) and the Holy Cross Mountains is much smaller, has a circular outline, and fewer but overall coarser costae with clearly preserved furrows. The flanks are smooth or covered anteriorly by very weak and broad costae with fine, short, but well developed furrows. Ivdelinia madmonica Sapelnikov \& Kartaschova, 2003 is more compact and with more ribs in the sulcus, furthermore, the furrows on the ribs are shorter than in I. pulchra. Ivdelinia praeivdelensis Sapelnikov in Sapelnikov \& Mizens, 2005 shows smaller and more compact forms with a coarser median furrow on the fold than the new species.
Ivdelinia lahuseni (Tschernyschew, 1885) shows smaller forms with higher and angular plications than in I. pulchra. Ivdelinia dissecta Malygina \& Sapelnikov, 1973, has a smooth fold with an angular and deep median furrow, a high and angular median plication in the fold and finer plications on its flanks than the bordering plications of the fold and sulcus, whereas in I. pulchra, the fold and sulcus show numerous plications, which are less deep and elevated. Furthermore, the plications on the fold, sulcus, and flanks are of equal size. Brice (1982) described I. grennellensis Brice, 1982 from the Arctic Canadian Islands. This species has a shorter ventral median septum, a more compact form, and 4 ribs on the fold. The furrows on the costae are almost invisible in her monograph, and the illustrated representatives of Li \& Jones (2002) show more costae on flanks, a shorter sulcus tongue, and weaker furrows on the costae. Ivdelinia pseudoivdelensis (Khodaievich, 1951) has smaller and more transverse shells with costae of unequal size, whereas I. pulchra has less transverse shells, larger specimens, and costae of equal size. The subspecies I. rectangularis quadruplicata (Torley, 1934) from Germany shows most similarities to I. pulchra, but this subspecies is smaller and has a more strongly transverse ornament than the new species. Besides the morphological differences described herein, no taxon of Ivdelinia has been reported from Givetian strata so far.

\section{Palaeobiogeographical and palaeoecological implications}

The origin of Ivdelinia lies without doubt in the Ural Mountains, where their highest diversity has been described from Eifelian strata. Outside Central Asia and the Ural Mountains, the first Ivdelinia appeared during the Emsian, and this agrees with a step-by-step loss of the Early Devonian endemism with a faunal migration pathways from Asia to Central Europe and North Africa (e.g., SchemmGregory \& Jansen 2008; Schemm-Gregory 2009a, b). Within the phylogenetic relationships of taxa of Ivdelinia shown by morphological similarities of the Ivdelinia faunas, a geographical relationship between Europe and North Africa can be confirmed. Additionally, as already proposed by Blodgett \& Boucot (1999) and Blodgett et al. (2002), a closer relationship of SW Alaska to the Urals than to the Canadian Arctic Islands appears plausible. Even though a single species of Ivdelinia occurs in the Canadian Arctic Islands and suggesting a faunal migration, the subgenus $I v$ delinella Brice, 1982 seems to be endemic for this region. The species Ivdelinia (Ivdelinella) salairica Gratsianova, 1998 would be the first taxon within this subgenus from Emsian strata; due to the lack of plications or only faint plications on the dorsal valve and the lack of the median 


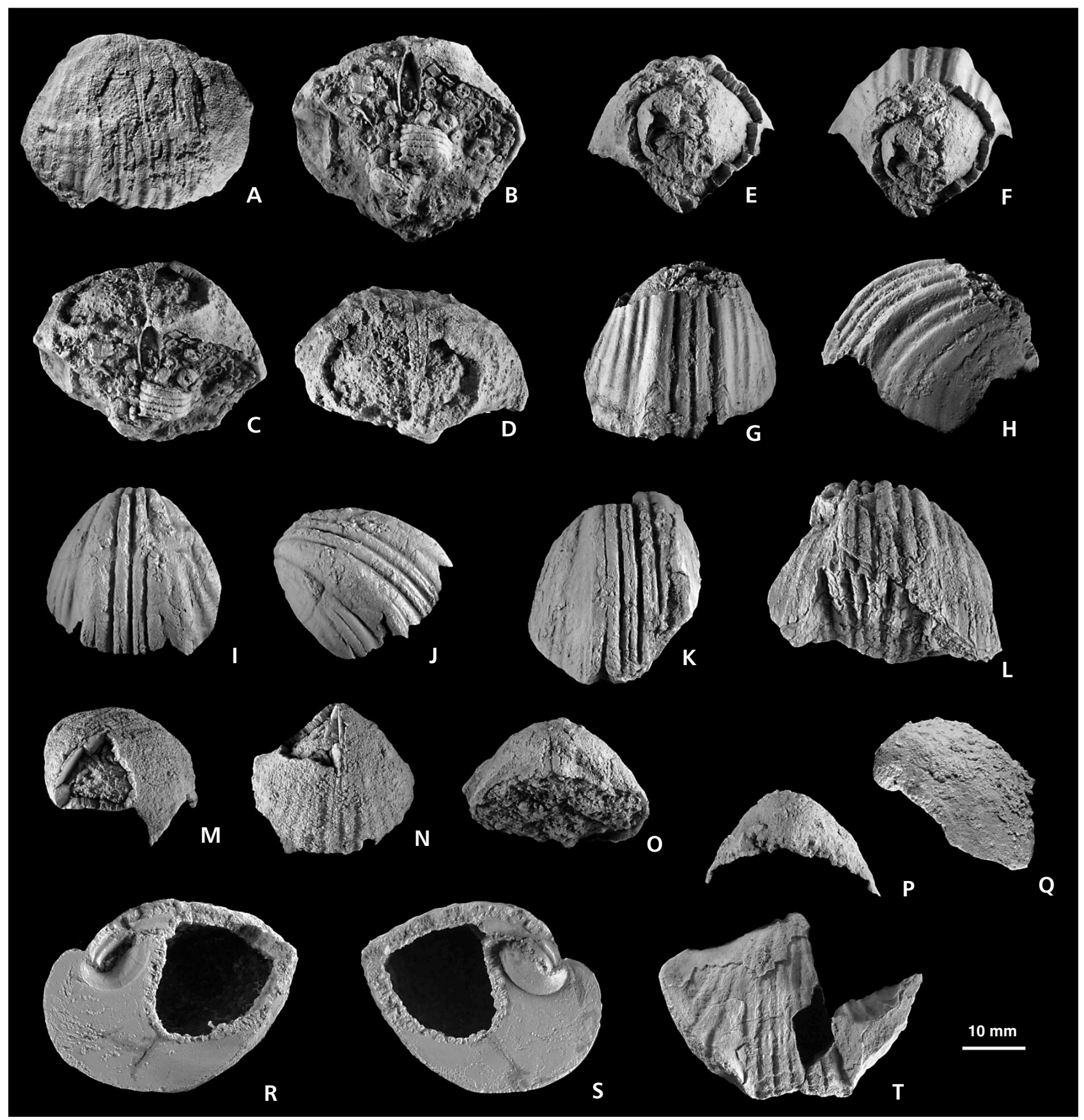

Figure 3. Ivdelinia pulchra sp. nov. $\bullet$ A-D - MGGC 21837. Ventral (A), dorsal (B), oblique posterodorsal (C), and oblique posterior (D) views of ventral valve; note the spondylium (B) and the ventral median septum (C). E-H - MGGC 21838. Posterior (E), oblique posterior (F), ventral (G), and oblique anterolateral (H) views of ventral external valve. $\bullet$ I, J - MGGC 21843. Ventral (I) and oblique anterolateral (F) views of ventral external valve. $\bullet$ K - MGGC 21839. Ventral view of ventral external valve; note furrows on ribs. $\bullet$ L-MGGC 28144. Anterior view of articulated shell; note furrows on ribs and margin of sulcus tongue. $\bullet \mathrm{M}, \mathrm{N}-\mathrm{MGGC} 21840$. Oblique posterolateral $(\mathrm{M})$ and ventral $(\mathrm{N})$ views of ventral external valve; note ventral median septum. $\bullet \mathrm{O}-\mathrm{MGGC}$ 21835. Oblique posterior view of ventral external valve. $\bullet P, Q-$ MGGC 21836. Posterior (P) and lateral (Q) views of ventral external valve. $\bullet$ R-T - MGGC 21842a, b. Holotype. Lateral (R, S) and dorsal views of articulated specimen; note spondylium, ventral median septum, and outline of dorsal valve. A-Q from Aferdou el Mrakib, north-eastern flank, southern Maïder Basin, Anti-Atlas, Morocco, leg. F. Franchi, February 2011. R-T from Aferdou El Mrakib, northwestern flank, southern Maïder, Anti-Atlas, Morocco, leg. C. Klug, March 2011. All specimens are Early Givetian age and original size (1.0×).

septum we attribute this taxon to Carinagypa Johnson \& Ludvigsen (1972) (personal communication R.B. Blodgett, 2011).
Gypidulid brachiopods are restricted to distinct environmental palaeohabitats. Jux (1969) reported that gypidulids are abundant in the turbiditic and fine grained sandstone and 


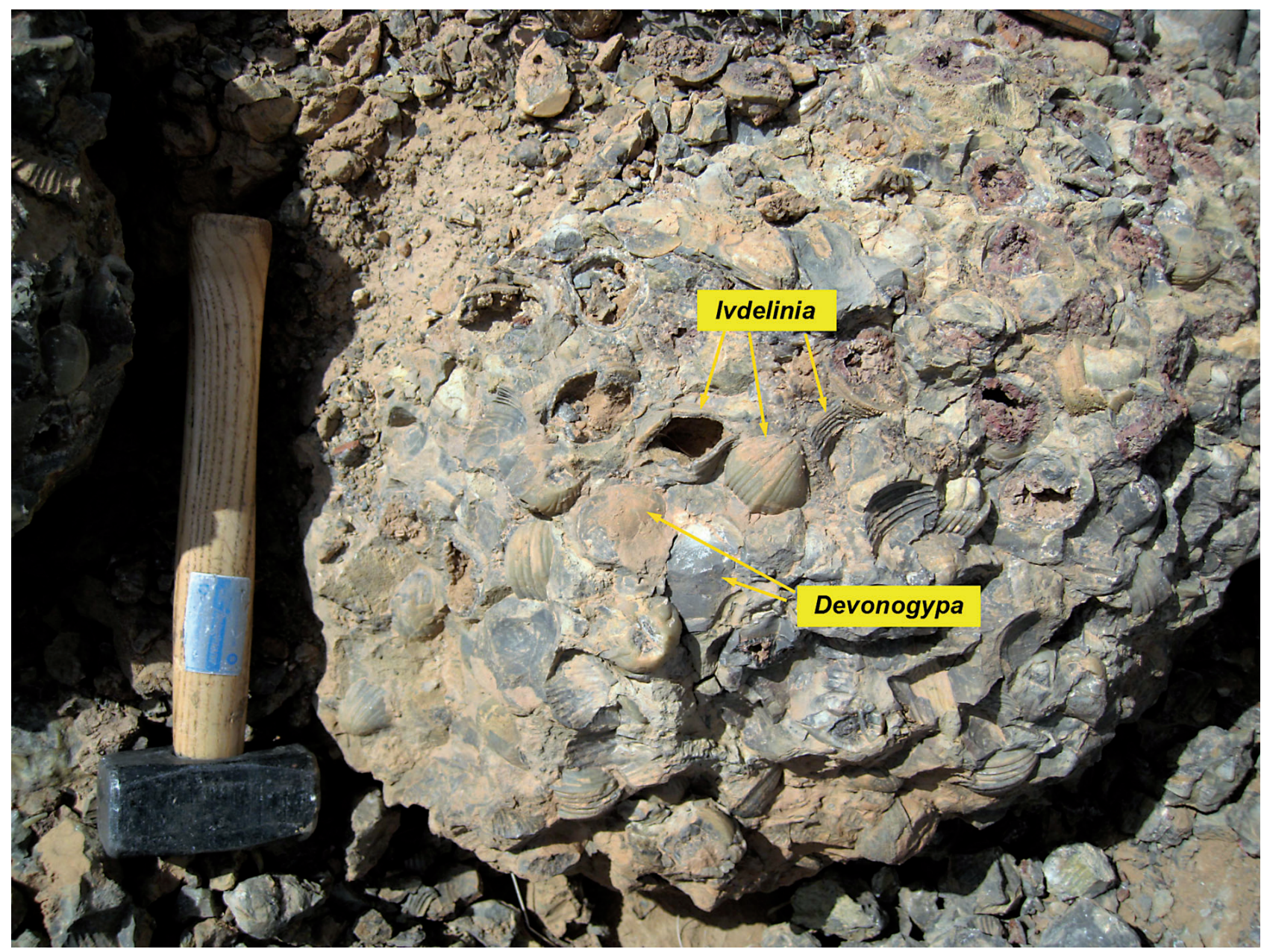

Figure 4. Mass-occurrence of Ivdelinia pulchra sp. nov. and Devonogypa sp. on Aferdou el Mrakib, northeastern flank.

marly limestone facies, gypidulid coquinas were also found in near shore plattenkalk facies. With a faunal assemblage made up of tabulate and rugose corals, atrypids, and rhynchonellids, the studied mud mounds of the Maïder Basin seem to represent a suitable palaeoenvironment for Ivdelinia. During ontogeny, ivdelinids probably reduced their pedicle and were dependent on a fine-grained substrate in which they were partly imbedded umbonally in a stable position. Furthermore, living in clusters also guarantees shelter from being transported by currents.

On Aferdou el Mrakib, mass-occurrences are remarkable (Fig. 4), where they co-occur with large Devonogypa, which apparently shared the same palaeoecological requirements. The patchy distribution across the bottom strata of Aferdou el Mrakib indicates a more or less allochthonous state of these occurrences. Apparently, they formed little forest-like or colony-like aggregations during the early stage of the reef growth. These brachiopods mass-occurrences, as well as the crinoid remains, acted as a substrate for the colonization by the reef builder communities. The abundance of bioclastic remains, specially crinoids, within the embedding dark rock, was already described elsewhere in the shallow platform facies in Tafilalt Basin and Maïder Basin, suggesting that the colonies bloomed in a quite turbulent environment (compatible with Gypidulid ecology) characterized by currents and not properly in the reef buildups. On the opposite in the other Anti-Atlas analogue basins, where no reef buildups were described, I. pulchra does not occur, which shows that this taxon is strongly related with the reef development.

Furthermore, we must consider that during Givetian age the Maïder Basin was situated at middle-high latitude (Stampfli \& Borel 2002) and water temperature must have been lower than in present day tropical platforms. Anyway the high latitude is comparable with the Urals latitudes throughout the Devonian, where Ivdelinia first occurred.

\section{Conclusion}

The new early Givetian ivdelinid species, Ivdelinia pulchra, represents the youngest Ivdelinia species described 
to date. It exhibits a characteristic morphology of fold and sulcus, as well as number of ribs enables an easy identification and, therefore, it might be a useful stratigraphic tool for the lower Givetian deposits of the Maïder Basin. Ivdelinia pulchra is suggested to have migrated near the Eifelian/Givetian boundary interval from today's Central Asia to Europe and North Africa.

Further at least mono specific assemblage of Devonogypa sp. and Ivdelinia pulchra is related to particular adaption to an environment characterized by high nutrient supply, turbid water and low temperatures in an high latitude intracratonic shallow sea during the early stage of reef development.

\section{Acknowledgements}

The authors thank Robert B. Blodgett (Anchorage, USA) and Michael Ricker (Senckenberg Forschungsinstitut und Naturmuseum Frankfurt, Germany) for provision of literature. FF thanks Roberto Barbieri (University of Bologna, Italy) for his suggestions during the preparation of this manuscript. CK thanks the Swiss National Science foundation for financial support for the fieldwork (Project number 200021-113956/ 1, 200020-25029, and 200020-132870). The Moroccan colleagues of the Ministère de l'Energie et des Mines (Rabat and Midelt) benignly provided permits for the field work and for the export of samples. This research is part of FF Ph.D. project financially supported by the MIUR-PRIN program "Comparative geomicrobiology of the mounds in the Moroccan Sahara: implications for Mars astrobiology". This is a contribution to the IGCP Project 596 "Climate Change and biodiversity Patterns in the Mid-Paleozoic".

\section{References}

Aitken, S.A., Collom, C.J., Henderson, C.M. \& Johnston, P.A. 2002. Stratigraphy, palaeoecology, and origin of Lower Devonian (Emsian) carbonate mud buildups, Hamar Laghdad, eastern Anti-Atlas, Morocco, Africa. Bulletin of Canadian Petroleum Geology 50, 217-243. DOI 10.2113/50.2.217

ANDronov, S.M. 1961. Nekotorye predstaviteli semeistva Pentameridae iz devonskikh otlozhenii okrestnostei g. Severouralska. Akademiya Nauk SSSR, Trudy Geologicheskogo Instituta 55, 1-136. [in Russian]

BARRANDE, J. 1879. Recherches paléontologiques. 5: Classe des Mollusque, Ordre de Brachiopodes. Systême silurien du centre de la Bohême 1, 1-226.

BelKA, Z. 1998. Early Devonian Kess-Kess carbonate mud mounds of the eastern Anti-Atlas (Morocco), and their relation to submarine hydrothermal venting. Journal of Sedimentary Research 68, 368-377.

Belka, Z., Kaufmann, B. \& Bultynck, P. 1997. A conodontbased quantitative biostratigraphy for the Eifelian of the eastern Anti-Atlas, Morocco. Geological Society of America Bulletin 109, 643-651.

DOI 10.1130/0016-7606(1997)109<0643:CBQBFT>2.3.CO;2
Biernat, G. 1966. Middle Devonian brachiopods of the Bodzentyn Syncline (Holy Cross Mountains, Poland). Palaeontologia Polonica 17, 1-162.

Blodgett, R.B. \& Boucot, A.J. 1999. Late Early Devonian (Late Emsian) eospiriferinid brachiopods from the Shellabarger Pass, south-central Alaska, and their biostratigraphic importance; further evidence for a Siberian origin of the Farewell and allied Alaskan accreted terranes. Senckenbergiana lethaea 79, 209-221.

Blodgett, R.B., Rohr, D.M. \& Boucot, A.J. 2002. Late links among some Alaskan accreted terranes and Siberia based on megafossils. Geological Society of America Special Paper 360, 273-290.

Blodgett, R.B., Boucot, A.J. \& Rong, J.Y. 2002. Gypiduloidea, 1005-1020. In KAESLER, R.L. (ed.) Treatise on Invertebrate Paleontology, Part H, Brachiopoda, revised, vol. 4. The Geological Society of America \& University of Kansas, Lawrence, Kansas.

Brachert, T.C., Buggisch, W. Flügel, E., HüsSner, H.M., JoACHIMski, M.M., Tourneur, F. \& Walliser, O.H. 1992. Controls of mud mound formation: the Early Devonian Kess-Kess carbonates of the Hamar Laghdad, Antiatlas, Morocco. Geologische Rundschau 81, 15-44.

DOI 10.1007/BF01764537

BRICE, D. 1982. Brachiopodes du Dévonien inférieur et moyen des formations de Blue Fiord et Bird Fiord des îles Arctiques Canadiennes. Geological Survey of Canada Bulletin 326, 1-75.

Burkhard, M., Caritg, S., Helg, U., Robert-Charrue, C. \& Soulaimani, A. 2006. Tectonics of the Anti-Atlas of Morocco. Comptes Rendus Geoscience 338(1-2), 11-24.

DOI 10.1016/j.crte.2005.11.012

Chafetz, H.S. \& BuCZYNSKi, C. 1992. Bacterially induced lithification of microbial mats. Palaios 7, 277-293. DOI 10.2307/3514973

Choubert, F., Clariond, L. \& Hintermeyer, J. 1952. Anti-Atlas central et oriental, 1-89. XIX Congres Géologie International, Algers, Livret Guide, Excursion C 36, Service Géologique du Maroc 11.

Dumestre, A. \& ILling, L.V. 1967. Middle Devonian reefs in Spanish Sahara, 333-350. In Oswald, D.H. (ed.) International Symposium on the Devonian System: Alberta Society of Petroleum Geologists 2.

FAGERSTROM, J.A. 1991. Reef-building guilds and a checklist for determining guild membership. Coral Reefs 10, 47-52. DOI 10.1007/BF00301908

Godefroid, J. 1972. Pseudosieberella (Pentameridae), noveau genre Couvinien, et genres apparentes. Institut Royale des Sciences Naturelles de Belgique, Bulletin 48(5), 1-41.

Gratsianova, R.T. 1998. New species of the genus Ivdelinia (Brachiopoda) from the Lower Devonian of the Salair and its significance for paleobiogeography. News of Paleontology and Stratigraphy 1 (Supplement to Russian Geology and Geophysics 39), 47-55. [in Russian]

HALL, J. 1867. Descriptions and figures of the fossil Brachiopoda of the Upper Helderberg, Hamilton, Portage and Chemung Groups. Palaeontology of New York 4(1), 1-428. 
Hollard, H. 1963. Un tableau stratigraphique du Dévonien du sud de l'Anti-Atlas. Notes et Mémoires du Service Géologique du Maroc 23, 105-109.

Hollard, H. 1967. Le Dévonian du Maroc et du Sahara nord-occidental, 203-244. In OswaLd, D.H. (ed.) International Symposium on the Devonian System 1. Alberta Society of Petroleum Geologists, Calgary.

HollaRd, H. 1974. Recherches sur la stratigraphie des formations du Dévonien moyen, de l'Emsien supérieur au Frasnien, dans le Sud du Tafilalt et dans le Maïder (Anti-Atlas oriental). Notes du Service Géologique du Maroc 264, 7-68.

Hollard, H. 1981a. Principaux caractères des formations dévoniennes de l'Anti-Atlas. Notes et Mémoires du Service Géologique du Maroc 42, 15-22.

Hollard, H. 1981b. Tableaux de corrélations du Silurien et du Dévonien de l'Anti-Atlas. Notes et Mémoires du Service Géologique du Maroc 42, 23.

Johnson, J.G. \& Ludvigsen, R. 1972. Carinagypa, a new genus of pentameracean brachiopod from the Devonian of western North America. Journal of Paleontology 46, 125-129.

Jux, U. 1969. Pentameriden aus dem Bergischen Devon. Palaeontographica A 132, 55-93.

Kaufmann, B. 1995. Middle Devonian mud mounds of the Ma'der Basin in the eastern Anti-Atlas, Morocco, 49-57. In Flajs, G., Vigener, M., Keupp, H., Meischner, D., Neuweiler, F., Paul, J., Reitner, J., Warnke, K., Weller, H., Dingle, P., Hensen, C., Schäfer, P., Gautret, P., Leinfelder, R.R., Hüssner, H. \& Kaufmann, B. Mud Mounds: A Polygenetic Spectrum of Fine-grained Carbonate Buildups. Facies 32.

Kaufmann, B. 1996. Facies, stratigraphy and diagenesis of Middle Devonian reef and mud-mounds in the Maïder (eastern Anti-Atlas, Morocco). PhD thesis, University of Tübingen.

Kaufmann, B. 1997. Diagenesis of Middle Devonian carbonate mud buildups of the Maïder Basin (eastern Anti-Atlas). Journal of Sedimentary Research A67, 945-956.

Kaufmann, B. 1998a. Middle Devonian reef and mud mounds on a carbonate ramp: Maïder Basin (eastern Anti-Atlas, Morocco), 417-435. In Wright, V.P. \& BuRChETTE, T.P. (eds) Carbonate Ramps. Geological Society of London, Special Pubblication 149.

KaUfMANN, B. 1998b. Facies, stratigraphy and diagenesis of Middle Devonian reef- and mud-mounds in the Maïder (eastern Anti-Atlas, Morocco). Acta Geologica Polonica 48, 43-106.

Khodalevich, A.N. 1951. Nizhnedevonskie i eifel'skie brakhiopody Sverdlovskoi oblasti. Sverdlovskii Gornyi Institut, Trudy 18, 1-169. [in Russian]

Khodalevich, A.N., \& Breivel, M.G. 1959. Nadsemeistvo Pentameracea (Superfamily Pentameracea), 14-41. In KHOdALEvich, A.N., Breivel, I.A., Breivel, M.G., Vaganova, T.I., Torbakova, A.F. \& Yanet, F.E. (eds) Brakhiopody $i$ korally iz Eifelskikh boksitonosnykh otlozhenii vostochnogo sklona srednego $i$ severnogo Urals. Ural'skoe geologicheskoe upravlenie, Gosgeoltekhizdat, Moskva. [in Russian]

Klug, C., Schulz, H. \& De Baets, K. 2009. Red trilobites with green eyes from the Early Devonian of the Tafilalt (Morocco).
Acta Palaeontologica Polonica 54, 117-123.

DOI 10.4202/app.2009.0112

Le Maître, D. 1952. Les faunes du Dévonien inférieur et moyen de la Saoura et des abords de l'Erg el Djemel (SudOranais)-carte géologique Algérie. Palaeontology 12, 1-170.

Li, R. \& Jones, B. 2002. Communities and paleoecology of Eifelian (mid-Devonian) brachiopods from the Bird Fiord Formation of Arctic Canada. Canadian Journal of Earth Science 39, 1485-1503. DOI 10.1139/e02-051

Malygina, A.A. \& Sapelnikov, V.P. 1973. Siluriskie, rannedevonskie i eifielskie Pentamerida zuzhnogo Tian'-shania. Akademia Nauk SSSR, Uralskii Nauchnyi Tsentr, Trudy Instituta Geologii i Geokhimii 104, 1-212. [in Russian]

Massa, D., Combaz, A. \& Manderscheid, G. 1965. Observations sur les Séries Siluro-Dévoniennes des confins AlgéroMarocains du Sud. Compagnie Française des Pétroles, Notes et Mémoires 8, 187-248.

Michard, A. 1976. Elements de Géologie Marocaine. Notes et Mémoires du Service Géologique du Maroc 252, 408.

MonTy, C.L.V. 1995. The rise and nature of carbonate mudmounds: an introductory actualistic approach, 11-48. In Monty, C.L.V., Bosence, D.W.J., Bridges, P.H. \& Pratt, B.R. (eds) Carbonate Mud-Mounds: their origin and evolution. International Association of Sedimentologists, Special Publication 23.

Roemer, C.F. in BronN, H.G. 1850-1856. Lethaea geognostica, oder Abbildungen und Beschreibungen für die GebirgsFormationen bezeichnendsten Versteinerungen. 352 pp. E. Schweizerbart'sche Verlagshandlung und Druckerei, Stuttgart.

SAndberger, F. in SAndberger, G. \& SAndberger, F. 1850-1856. Die Versteinerungen des Rheinischen Schichtensystems bei Nassau. 564 pp. Kreidel und Niedner, Wiesbaden.

SAPELnikov, V.P. 1985. Sistema i stratigraficheskoe znachenie brakhiopod podotriada Pentamerida. 206 pp. Nauka, Moscow. [in Russian]

Sapelnikov, V.P. \& Kartaschova, L.E. 2003. Ezhegodnik 2002. Novye vidy rannedevonskikh brachiopod zeravshanskogo khrebta (Yuzhnyi Tyan'-Shan'), 38-44. Institut geologii i geokhimii, Ural'skoe otdelenie, Rossiyskaya Akademiya Nauk, Moskva. [in Russian]

SAPELnikov, V.P. \& Mizens, L.I. 2005. Brachiopods from the type locality of the Pragian-Emsian boundary (Devonian). Senckenbergiana lethaea 85, 13-29.

SCHEMm-GREGORY, M. 2009a. Frequentispirifer, a new spiriferid genus and its phylogenetic position within the Delthyridoidea (Brachiopoda, Lower Devonian). Neues Jahrbuch für Geologie und Paläontologie, Abhandlungen 251, 53-70. DOI 10.1127/0077-7749/2009/0251-0053

SCHEMm-Gregory, M. 2009b. On the genus Quiringites Struve, 1992 (Brachiopoda, Middle Devonian). Bulletin of the Peabody Museum of Natural History 50, 3-20. DOI 10.3374/014.050.0101

Schemm-Gregory, M. \& JANSEN, U. 2008. First report of the stringocephalid genus Paracrothyris (Brachiopoda, Middle 
Devonian) from North Africa. Bulletin of Geosciences 83, 169-173. DOI 10.3140/bull.geosci.2008.02.169

SChuChert, C. \& Le Vene, C.M. 1929. Brachiopoda (Generum et Genotyporum Index et Bibliographia), 1-140. In POMPECKJ, J.F. (ed.) Fossilium Catalogus I: Animalia, pars 42: Brachiopoda. W. Junk, Berlin.

SCHUCHERT, C. \& COOPER, G.A. 1931. Synopsis of the brachiopod genera of the suborders Orthoidea and Pentameroidea, with notes on the Telotremata. American Journal of Science (series 5) $22,241-255$.

StAmpfli, G.M. \& Borel, G.D. 2002. A plate tectonic model for the Paleozoic and Mesozoic constrained by dynamic plate boundaries and restored synthetic oceanic isochrons. Earth and Planetary Science Letters 196, 17-33. DOI 10.1016/S0012-821X(01)00588-X

ToRLEy, K. 1934. Die Brachiopoden des oberen Massenkalkes von Bilveringen bei Iserlohn. Abhandlungen der senckenbergischen naturforschenden Gesellschaft 43 (3), 67-148.

TsChERNYSCHEw, T.N. 1885. Die Fauna des unteren Devon am West-Abhange des Urals. Trudy Geologicheskogo Komiteta 3(1), 1-107.

WENDT, J. 1985. Disintegration of the continental margin of northwestern Gondwana: Late Devonian of the eastern AntiAtlas (Morocco). Geology 13, 815-818.

DOI 10.1130/0091-7613(1985)13<815:DOTCMO>2.0.CO;2
WendT, J. 1988. Facies pattern and paleogeography of the Middle and Late Devonian in the eastern Anti-Atlas (Morocco), 467-480. In McMillan, N.J., Embry, A.F. \& Glass, D.J. (eds) Canadian Society of Petroleum Geologists, Devonian of the World 1.

WendT, J. 1991. Depositional and structural evolution of the Middle and Late Devonian on the northwestern margin of the Sahara Craton (Morocco, Algeria, Libya), 2195-2210. In SALEM, M.J., Sbeta, A.M. \& BAKвAK, M.R. (eds) The Geology of Libya 6. Elsevier, Amsterdam.

WENDT, J. 1993. Steep-sided carbonate mud mounds in the Middle Devonian of the eastern Anti-Atlas, Morocco. Geological Magazine 130, 69-83. DOI 10.1017/S0016756800023736

Wendt, J., Belka, Z., Kaufmann, B., Kostrewa, R. \& Hayer, J. 1997. The world's most spectacular carbonate mud mounds (Middle Devonian, Algerian Sahara). Journal of Sedimentary Research 67, 424-436.

Wendt, J., Belka, Z. \& Moussine-Pouchine, A. 1993. New architectures of deep-water carbonate buildups: Evolution of mud mounds into mud ridges (Middle Devonian, Algerian Sahara). Geology 21, 723-726.

DOI 10.1130/0091-7613(1993)021<0723:NAODWC >2.3.CO;2

Wright, V.P. 1992. A revised classification of limestones. Sedimentary Geology 76(3-4), 177-185. DOI 10.1016/0037-0738(92)90082-3 